\title{
Training effects of modern artistic exercises in improving some physical variables and sensory system among rhythmic gymnasts under (12) years
}

\section{Prof. Dr. / Ashraf Abdelal Alzohary}

\author{
Prof. Dr. / Eslam Mohamed Mahmoud Salim
}

\section{Dr. Lamiaa Mohamed Gouda}

\section{- Summary:}

The aim of the research to identify the training effects of modern artistic exercises in improving some physical variables and the sensory system among rhythmic gymnastics players under (12) years, and the experimental approach with a single experimental group was used in the way of tribal, inter-dimensional, and measurements, and the study was applied to a sample consisting of (10) gymnastics players In the Alexandria Union Club, and the researchers designed a program for modern technical exercises, and it was trained for a period of (12) weeks, at the rate of (3) weekly training units.

The most important results were that the use of modern artistic exercises represented by free exercises and tools led to the improvement of some physical defects and elements of the sensory system and the level of skill performance of female rhythmic gymnasts under (12) years.

Through this, researchers are recommended to use modern artistic exercises to improve physical expressions, elements of the sensory system, and the level of skill performance of rhythmic gymnasts, and to conduct similar studies to find out the effect of modern artistic exercises on various sports activities.

\section{- Introduction:}

Modern artistic exercises are characterized by aesthetics and emotional expression, as they link basic and rhythmic exercises with acrobatic movements, dance and ballet with musical accompaniment, and they are performed with or without tools, individually or collectively, and internal championships and international competitions are held for them, and they follow rules and laws that define the ways to award grades and calculate the difficulty of movements and Genesis. (23: 18), (21: 9).

The direction and control of motor and skill performance depends on the level of growth and development of the functional characteristics of a number of psychological processes that represent the basic basis for directing and controlling performance. (40:25)

\footnotetext{
* Professor of Gymnastics Training and Head of the Training and Gymnastics Training Department - Faculty of Physical Education for Boys - Alexandria University.

** Professor of Exercise Training and Sports Shows, Department of Training and Gymnastics Training - Faculty of Physical Education for Boys - Alexandria University.

*** Senior tutor supervisor at the Ministry of Education.
} 
The main sensory systems are the visual system, vestibular apparatus, and somatosensory receptors. (9: 137)

The sense of sight is the most valuable and most beneficial to the human senses, and the visual system represents the main effect of balance, as it provides the body with information about the environmental environment, location, and the speed of movement of persons. (46: 161)

The visual system affects the balance control of situations where other sensory systems fail, and when there is a conflict of sensory information about the sensory system responsible for the equilibrium process. (45:41), and the effectiveness of performance in many motor activities depends on the level of functional competence of the vision analyst in distinguishing goals, and the exercise of these activities leads to an increase in his efficiency. (24:37)

The vestibular apparatus integrates with the visual system and the sensory sensory systems to stabilize the balance, and is characterized by being the most physically stable of the three systems. When it issues initial signals from the middle ear, it begins to perform its tasks of stabilizing the balance by controlling the body's balance by reflections from the thorn system vestibular and cerebellum, which interacts with the cerebral cortex with data from the visual system - vestibular by the inner nodes of the middle ear, secreting an inhibitory factor that affects vestibular nuclei, in addition to the signals from the visual system, which in turn support Vestibular response to the cerebellum eventually adjusting, modifying, and modeling data to produce the final reaction by proportioning the eye and the head velocity. (43:41), (9: 137)

The somatosensory receptors are one of the components of the hierarchical system of the central nervous system that begins to function since the reception of signals and their translation, and this system provides the body with two types of information represented in the (muscular sensory self-receptors and articulated inputs, then it sends signals about the joint position and the type of movement, and mechanical receptors in the soles of the foot reach Signs of pressure change patterns and the momentum force that results from body movements), and both of these types of information can determine the degree and quality of disturbances occurring in an individual's balance during stability or movement to induce motor control. (44: 159)

The sense of time is related to rhythm and motor timing to complete motor skills in a timely manner, because of its great importance in sports activities. (15:14), and it is considered one of the most important elements leading to linking the various kinetic elements in the overall unit of kinetic performance. $(8: 21)$

The sense of time depends on the training condition, when the mathematical form decreases, the sense of time decreases, and if it rises, an improvement in the ability to accurately distinguish the spatial and temporal characteristics of the movement decreases. (11:227)

In view of the interest in the field of rhythmic gymnastics and its follow-up with different clubs, the study aimed to identify the training effects of modern artistic exercises and its importance in improving some physical variables and the sensory system and the development of both the visual, muscular and kinesthetic sense of time for female rhythmic gymnasts. 


\section{- Research Objective:}

Identify the training effects of modern artistic exercises in improving some physical variables and the sensory system among rhythmic gymnasts under (12) years.

\section{- Research hypotheses:}

- There are statistically significant differences between the tribal, intra and dimensional measurements in the physical variables under discussion among rhythmic gymnasts.

- There are statistically significant differences between the tribal, intra and dimensional measurements in the sensory system components under discussion among rhythmic gymnasts.

- There are statistically significant differences between the tribal, intra and dimensional measurements in the level of sensory skill performance under discussion among rhythmic gymnasts.

\section{- Search procedures :}

- Research Methodology :

The experimental method with the same experimental group was used in the method of tribal, inter-dimensional and measurements measurements, as it suits the nature of the research.

The human domain:

The players of Al-Ittihad of Alexandria club, whose number is (17).

\section{- Time domain:}

The study was conducted from 14/2/2017 to 5/30/2017 as follows:

1- The surveys were conducted in the period from $2 / 14 / 2017$ to $2 / 18 / 2017$.

2- The tribal measurements were carried out from $21 / 2 / 2017$ to $25 / 2 / 2017$.

3- The basic study was conducted in the period from $26 / 2 / 2017$ to $5 / 30 / 2017$.

4- Interlayer measurements were carried out from 4/14/2017 to 4/18/2017.

5- Dimensional measurements were carried out from 25/5/2017 to 5/30/2017.

\section{- Location:}

Alexandria Union Club.

\section{- The research sample :}

The basic study was applied to an intentional sample of (10) gymnasts who represented (58.8\%) of the total original community in the Alexandria Union Club.

While reconnaissance studies were applied to a sample of (7) gymnasts from outside the main study sample. 


\section{- Pilot studies:}

\section{First pilot study:}

The selection and determination of the most appropriate physical tests and measurements, the components of the sensory system, the level of skill performance in the skills of modern technical exercises, and resulted in the identification of these tests. Attachment (1)

\section{The pilot study:}

Calculation of scientific coefficients for measurements and tests under study. Tables (1), (2), (3), (4), (5), (6). Attachment (2)

\section{The Third pilot study:}

Define the exercises and design the training program. Attachment (4)

\section{- The tools and devices used to carry out the experiment:}

Medical scale Criteria for measuring weight in kilograms - Restimeter for measuring height in centimeters - Dynamometer for measuring muscle strength - Balance beam for measuring movement balance - Stopwatch for measuring time - Digital camera with a special holder Measuring tape in centimeters - Rug - Rhythmic gymnastics - Divided boxes - Jumping ladder Spring ropes - medical balls of different weights - plastic balls - collars - Swedish seats.

\section{- Statistical treatments:}

The Spss statistical program was used to extract the following statistical treatments:

Arithmetic mean - standard deviation - difference coefficient - torsional coefficient - flattening coefficient - difference between the two averages - value $(\mathrm{T})$ - honesty coefficient - correlation coefficient - percentage improvement - percentage of differences - analysis of variance (P) L.S.D

Table (7)

Statistical description of the data of the total research sample in the main variables before the experiment $\mathbf{n}=\mathbf{1 0}$

\begin{tabular}{c|c|c|c|c|c|c|c}
\hline \multicolumn{2}{c|}{$\begin{array}{c}\text { statistics } \\
\text { variables }\end{array}$} & $\begin{array}{c}\text { measurem } \\
\text { ent unit }\end{array}$ & Mean & $\begin{array}{c}\text { Standard } \\
\text { deviation }\end{array}$ & $\begin{array}{c}\text { Skewness } \\
\text { coefficient }\end{array}$ & $\begin{array}{c}\text { Coefficient } \\
\text { kurtosis }\end{array}$ & $\begin{array}{c}\text { Coefficient of } \\
\text { variation\% }\end{array}$ \\
\hline \multirow{3}{*}{$\begin{array}{c}\text { Basic } \\
\text { variab } \\
\text { les }\end{array}$} & Age & Year & 11.40 & 0.52 & $0.48-$ & -2.22 & 4.53 \\
\cline { 2 - 9 } & Height & $\mathrm{cm}$ & 137.10 & 3.38 & 0.15 & -1.40 & 2.47 \\
\cline { 2 - 9 } & Weight & $\mathrm{Kg}$ & 36.10 & 2.47 & 0.36 & -1.52 & 6.84 \\
\hline
\end{tabular}

It is clear from Table (7) for the homogeneity of the data of the research sample in the main variables that the values of the torsion coefficient ranged between $(-0.48,0.98)$ which are values between \pm 3 and approach to zero, and this confirms that the sample is free from defects of nonmoderate distributions, as well The values of the coefficient of variation ranged between $(2.47 \%$ $-8.07 \%$ ) which is less than $20 \%$ of the average, which indicates the homogeneity of the research personnel in all variables under investigation. 
Table (8)

Statistical indications of physical variables for the total sample in question $\mathbf{n}=\mathbf{1 0}$

\begin{tabular}{|c|c|c|c|c|c|c|c|}
\hline \multicolumn{2}{|c|}{$\begin{array}{c}\text { statistics } \\
\text { Physical vartables }\end{array}$} & \multirow{2}{*}{$\begin{array}{c}\begin{array}{c}\text { measure } \\
\text { ment } \\
\text { unit }\end{array} \\
\mathrm{Kg}\end{array}$} & \multirow{2}{*}{$\begin{array}{l}\text { Mean } \\
10.70\end{array}$} & \multirow{2}{*}{$\begin{array}{c}\begin{array}{c}\text { Standard } \\
\text { deviation }\end{array} \\
1.95\end{array}$} & \multirow{2}{*}{$\begin{array}{c}\text { Skewness } \\
\text { coefficient }\end{array}$} & \multirow{2}{*}{$\begin{array}{c}\begin{array}{c}\text { Coefficient } \\
\text { kurtosis }\end{array} \\
-1.83\end{array}$} & \multirow{2}{*}{$\begin{array}{c}\begin{array}{c}\text { Coefficient } \\
\text { of } \\
\text { variation } \%\end{array} \\
18.19\end{array}$} \\
\hline Fixed & Right fist force & & & & & & \\
\hline $\begin{array}{l}\max 1 \mathrm{mu} \\
\mathrm{m} \text { force }\end{array}$ & Left fist force & $\overline{\mathrm{Kg}}$ & 10.80 & 2.15 & 0.31 & -1.22 & 19.92 \\
\hline \multirow{2}{*}{$\begin{array}{c}\text { Distincti } \\
\text { ve force } \\
\text { speed }\end{array}$} & $\begin{array}{c}\text { Lift the two men out of } \\
\text { sleep in } 30 \mathrm{w}\end{array}$ & Number & 18.70 & 1.77 & 0.27 & 0.01 & 9.45 \\
\hline & $\begin{array}{c}\text { Bend the arms from the } \\
\text { oblique flatness } 30 \mathrm{w}\end{array}$ & Number & 12.50 & 0.53 & 0.00 & -2.57 & 4.22 \\
\hline Ability & Wide jump & $\mathrm{cm}$ & 137.40 & 11.42 & -0.52 & -1.61 & 8.31 \\
\hline $\begin{array}{c}\text { Compati } \\
\text { bility }\end{array}$ & Skipping rope & Number & 1.50 & 0.23 & 0.23 & -2.57 & 15.14 \\
\hline \multirow{3}{*}{$\begin{array}{c}\text { Flexibili } \\
\text { ty }\end{array}$} & $\begin{array}{c}\text { Drape the trunk in front } \\
\text { of the bottom }\end{array}$ & $\mathrm{cm}$ & 12.00 & 1.56 & -0.22 & -1.34 & 13.03 \\
\hline & The torso folded behind & $\mathrm{cm}$ & 8.90 & 1.73 & 0.03 & 0.10 & 19.43 \\
\hline & $\begin{array}{c}\text { The two men opened a } \\
\text { grand car }\end{array}$ & $\mathrm{cm}$ & 1.50 & 0.28 & -0.89 & -0.16 & 18.67 \\
\hline \multirow{2}{*}{ Balance } & Stand on one foot & Second & 5.70 & 1.09 & 0.64 & -0.99 & 19.20 \\
\hline & $\begin{array}{l}\text { Running on the balance } \\
\text { beam }\end{array}$ & Second & 8.30 & 0.82 & -1.58 & 0.98 & 9.88 \\
\hline Agility & Rebound run & Second & 73.10 & 2.33 & 0.05 & -0.91 & 3.19 \\
\hline
\end{tabular}

It is clear from Table (8) for the homogeneity of the data of the research sample in the physical variables that the values of the torsion coefficient ranged between $(-1.58,0.64)$ which are values between \pm 3 and approach to zero, and this confirms that the sample is free from defects of nonmoderate distributions, as well The values of the coefficient of variation ranged between $(3.19 \%$ $-19.92 \%$ ) which is less than $20 \%$ of the mean, indicating the homogeneity of the research personnel in all variables under investigation.

Table (9)

Statistical indications of the variables of the sensory system elements of the total sample in question $\mathbf{n}=10$

\begin{tabular}{c|c|c|c|c|c|c}
\hline $\begin{array}{c}\text { statistics } \\
\text { Sensory systemetements }\end{array}$ & $\begin{array}{c}\text { measur } \\
\text { ement } \\
\text { unit }\end{array}$ & Mean & $\begin{array}{c}\text { Standard } \\
\text { deviation }\end{array}$ & $\begin{array}{c}\text { Skewness } \\
\text { coefficient }\end{array}$ & $\begin{array}{c}\text { Coefficient } \\
\text { kurtosis }\end{array}$ & $\begin{array}{c}\text { Coefficient } \\
\text { of } \\
\text { variation\% }\end{array}$ \\
\hline Error sensing the jump distance & $\mathrm{cm}$ & 10.70 & 1.95 & 0.21 & -0.88 & 18.18 \\
\hline $\begin{array}{c}\text { Error sensing a distance without } \\
\text { visual control }\end{array}$ & $\mathrm{cm}$ & 68.00 & 10.33 & -0.27 & -0.90 & 15.19 \\
\hline Wrong sense of time & Second & 8.10 & 1.20 & -1.20 & 0.14 & 14.78 \\
\hline Feeling of force & $\mathrm{Kg}$ & 6.50 & 1.18 & 0.42 & -1.73 & 18.17 \\
\hline
\end{tabular}

It is clear from Table (9) for the homogeneity of the research sample data in the sensory system elements that the values of the torsional coefficient ranged between $(-1.20$ and 0.42$)$ which are values between \pm 3 and approach to zero, and this confirms that the sample is free from defects of non-moderate distributions, Likewise, the values of the coefficient of variation ranged 
between $(14.78 \%-18.18 \%)$, which is less than $20 \%$ of the average, indicating the homogeneity of the research personnel in all variables under investigation.

Table (10)

Statistical indications of the skill level of the total sample in question $\mathbf{n}=\mathbf{1 0}$

\begin{tabular}{c|c|c|c|c|c|c}
\hline statistics \\
Skill performance level & $\begin{array}{c}\text { measur } \\
\text { ement } \\
\text { unit }\end{array}$ & Mean & $\begin{array}{c}\text { Standard } \\
\text { deviation }\end{array}$ & $\begin{array}{c}\text { Skewness } \\
\text { coefficient }\end{array}$ & $\begin{array}{c}\text { Coefficient } \\
\text { kurtosis }\end{array}$ & $\begin{array}{c}\text { Coefficient } \\
\text { of } \\
\text { variation\% }\end{array}$ \\
\hline Gap Dart Skill & mark & 5.30 & 0.82 & -0.69 & -1.04 & 15.53 \\
\hline $\begin{array}{c}\text { Weighted man free and Musk } \\
\text { behind (Catchback) }\end{array}$ & mark & 4.40 & 0.84 & -1.00 & -0.67 & 19.17 \\
\hline $\begin{array}{c}\text { The rotation of the free man is } \\
\text { horizontal }\end{array}$ & mark & 4.30 & 0.67 & 2.28 & 4.77 & 15.70 \\
\hline
\end{tabular}

It is clear from Table (10) for the homogeneity of the research sample data in the skill performance level that the values of the torsion coefficient ranged between (-1.00 and 2.28) which are values between \pm 3 and approach to zero, and this confirms that the sample is free from defects of non-moderate distributions, Likewise, the values of the coefficient of variation ranged between $(15.53 \%-19.17 \%)$, which is less than $20 \%$ of the average, which indicates the homogeneity of the research personnel in all variables under investigation.

\section{- Basic experience:}

The study started by applying the program as follows:

- Pilot group: underwent a training program for modern technical exercises.

- Training Program: Attachment (4)

- The circular training method was used to apply the intensity (low-high) intensity training, taking into account the increased pregnancy through gradual increase in pregnancy and continuity.

- The experiment lasted for a period of (12) weeks, with (3) weekly training units.

- The number of training educational units for the offer reached (36) units.

The principle of pregnancy and rest was used as a basis for training.

Average performance time for each exercise is 30 seconds.

Average time to rest (45) seconds.

- (Including it from registrations and moving to the next station to perform the next exercise using warm-up exercises $45 \mathrm{w}$, at the moment when the average number of heartbeat reached approximately 120 beats / $\mathrm{s}$.

- After teaching the correct performance of the exercises, the maximum number of iterations was calculated, then dividing the maximum number of repeats for each exercise $\div 2$.

- The number of groups in the training unit from (3) to (5). 
Average rest time between groups in the training unit from $(3 \mathrm{BC})$ to $(5 \mathrm{BC})$.

The mean rest time was calculated after returning the pulse rate from 120: 130 beats / min. (20: 262 - 263), (19: $386-387)$

\section{- Results and discussion:}

- Results:

Table (11)

Statistical indications of physical variables of the experimental group before, between, and after the experiment

\begin{tabular}{|c|c|c|c|c|c|c|c|c|c|}
\hline \multirow[t]{2}{*}{$\times$} & \multirow[t]{2}{*}{ statistics } & \multirow{2}{*}{$\begin{array}{c}\text { measure } \\
\text { ment } \\
\text { unit }\end{array}$} & \multicolumn{2}{|c|}{$\begin{array}{c}\text { Pre } \\
\text { measurement }\end{array}$} & \multicolumn{2}{|c|}{ between measurement } & \multicolumn{2}{|c|}{$\begin{array}{c}\text { Post } \\
\text { measurement }\end{array}$} & \multirow{2}{*}{$\begin{array}{c}\mathrm{F} \\
\text { Values }\end{array}$} \\
\hline & & & Mean & SD & Mean & SD & Mean & SD & \\
\hline \multirow{2}{*}{$\begin{array}{c}\text { Fixed } \\
\text { maximu } \\
\mathrm{m} \text { force }\end{array}$} & Right fist force & $\mathrm{Kg}$ & 10.70 & 1.95 & 11.30 & 1.64 & 13.40 & 1.78 & $146.68 *$ \\
\hline & Left fist force & $\mathrm{Kg}$ & 10.80 & 2.15 & 11.80 & 2.10 & 13.50 & 2.07 & $70.86^{*}$ \\
\hline \multirow{2}{*}{$\begin{array}{c}\text { Distincti } \\
\text { ve force } \\
\text { speed }\end{array}$} & $\begin{array}{l}\text { Lift the two men out of } \\
\text { sleep in } 30 \mathrm{w}\end{array}$ & Number & 18.70 & 1.77 & 22.10 & 1.73 & 27.20 & 1.62 & $130.39 *$ \\
\hline & $\begin{array}{l}\text { Bend the arms from the } \\
\text { oblique flatness } 30 \mathrm{w}\end{array}$ & Number & 12.50 & 0.53 & 14.90 & 1.20 & 21.00 & 1.33 & $347.98 *$ \\
\hline Ability & Wide jump & $\mathrm{cm}$ & 137.40 & 11.42 & 143.90 & 13.77 & 153.20 & 11.88 & $36.61 *$ \\
\hline $\begin{array}{c}\text { Compati } \\
\text { bility }\end{array}$ & Skipping rope & Number & 1.50 & 0.23 & 2.90 & 0.57 & 4.70 & 0.48 & $119.79 *$ \\
\hline \multirow{3}{*}{$\begin{array}{c}\text { Flexibili } \\
\text { ty }\end{array}$} & $\begin{array}{l}\text { Drape the trunk in front of } \\
\text { the bottom }\end{array}$ & $\mathrm{cm}$ & 12.00 & 1.56 & 9.20 & 1.14 & 4.50 & 1.18 & $138.01 *$ \\
\hline & The torso folded behind & $\mathrm{cm}$ & 8.90 & 1.73 & 5.50 & 0.71 & 2.70 & 0.67 & $109.36^{*}$ \\
\hline & $\begin{array}{c}\text { The two men opened a } \\
\text { grand car }\end{array}$ & $\mathrm{cm}$ & 1.50 & 0.71 & 4.10 & 0.74 & 7.70 & 1.34 & $161.56^{*}$ \\
\hline \multirow[b]{2}{*}{ Balance } & Stand on one foot & Second & 5.70 & 1.09 & 7.50 & 1.08 & 11.70 & 0.82 & $108.46^{*}$ \\
\hline & $\begin{array}{l}\text { Running on the balance } \\
\text { beam }\end{array}$ & Second & 8.30 & 0.82 & 6.35 & 0.82 & 3.90 & 0.21 & $231.26^{*}$ \\
\hline Agility & Rebound run & Second & 73.10 & 2.33 & 65.90 & 3.21 & 55.40 & 1.65 & $144.44 *$ \\
\hline
\end{tabular}

* Significant at 0.05 level (F significant $=3.34)$

From the table (11) on the statistical significance of the physical variables of the experimental group before, between, and after the experiment, it is clear that there are statistically significant differences at the level of 0.05 , between the pre and inter-dimensional measurements in all the physical variables under investigation, where the values of the calculated $p$ within the measurements ranged between $(36.61,347.98)$ and these values are greater than the tabular $(P)$ value at 0.05 .

The least significant difference (L.S.D) was calculated for the difference between the mean of the physical variables of the experimental group before, between, and after the experiment, and the improvement ratios were calculated. My schedule (12) and (13). Attachment (3) 
Table (14)

Statistical indications of the variables of the sensory system elements of the experimental group before, between, and after the experiment

\begin{tabular}{|c|c|c|c|c|c|c|c|c|}
\hline \multirow[b]{2}{*}{ Sensory system elements } & \multirow{2}{*}{$\begin{array}{l}\text { measureme } \\
\text { nt unit }\end{array}$} & \multicolumn{2}{|c|}{$\begin{array}{c}\text { Pre } \\
\text { measurement }\end{array}$} & \multicolumn{2}{|c|}{$\begin{array}{c}\text { between } \\
\text { measurement }\end{array}$} & \multicolumn{2}{|c|}{$\begin{array}{c}\text { Post } \\
\text { measurement }\end{array}$} & \multirow{2}{*}{$\begin{array}{c}\mathrm{F} \\
\text { Values }\end{array}$} \\
\hline & & Mean & SD & Mean & SD & Mean & $\mathrm{SD}$ & \\
\hline Error sensing the jump distance & $\mathrm{cm}$ & 10.70 & 1.95 & 5.60 & 2.32 & 1.60 & 1.17 & $63.90 *$ \\
\hline $\begin{array}{c}\text { Error sensing a distance without } \\
\text { visual control }\end{array}$ & $\mathrm{cm}$ & 68.00 & 10.33 & 41.00 & 9.94 & 12.50 & 2.64 & $93.78 *$ \\
\hline Wrong sense of time & Second & 8.10 & 1.20 & 3.50 & 0.97 & 1.10 & 0.99 & $176.10 *$ \\
\hline Feeling of force & $\overline{\mathrm{Kg}}$ & 6.50 & 1.18 & 3.20 & 0.79 & 0.40 & 0.52 & $67.49 *$ \\
\hline
\end{tabular}

* Significant at 0.05 level ( $\mathrm{F}$ significant $=3.34$ )

It is clear from the table (14) of the statistical significance of the variables of the sensory system elements of the experimental group before, between, and after the experiment, that there are statistically significant differences at the level of 0.05 , between the tribal and interdimensional measurements in all the physical variables under consideration, where the values of the calculated $p$ within the measurements ranged between $(63.90,176.10)$ These values are greater than the tabular value $(\mathrm{P})$ at the level of 0.05 .

The least significant difference (L.S.D) was calculated for the difference between the averages of the variables of the sensory system elements of the experimental group before, between, and after the experiment, and the improvement ratios were calculated. My schedule (15), (16). Attachment (3)

Table (17)

Statistical indications of the skill level of the total sample in question $\mathbf{n}=10$

\begin{tabular}{|c|c|c|c|c|c|c|c|c|}
\hline \multirow{2}{*}{ Skill performance Kevel } & \multirow{2}{*}{$\begin{array}{l}\text { measure } \\
\text { ment uni }\end{array}$} & \multicolumn{2}{|c|}{$\begin{array}{c}\text { Pre } \\
\text { measurement }\end{array}$} & \multicolumn{2}{|c|}{$\begin{array}{c}\text { between } \\
\text { measurement }\end{array}$} & \multicolumn{2}{|c|}{$\begin{array}{c}\text { Post } \\
\text { measurement }\end{array}$} & \multirow[t]{2}{*}{$\begin{array}{c}\mathrm{F} \\
\text { Values }\end{array}$} \\
\hline & & Mean & SD & Mean & $\mathrm{SD}$ & Mean & $\mathrm{SD}$ & \\
\hline Gap Dart Skill & mark & 5.30 & 0.82 & 7.60 & 0.70 & 9.80 & 0.42 & $150.23 *$ \\
\hline $\begin{array}{c}\text { Weighted man free and Musk } \\
\text { behind (Catchback) }\end{array}$ & mark & 4.40 & 0.84 & 6.70 & 0.48 & 9.50 & 0.71 & $212.20 *$ \\
\hline $\begin{array}{c}\text { The rotation of the free man is } \\
\text { horizontal }\end{array}$ & mark & 4.30 & 0.67 & 7.00 & 0.67 & 9.10 & 0.74 & $363.56^{*}$ \\
\hline
\end{tabular}

* Significant at 0.05 level (F significant $=3.34$ )

From the table (17) of the statistical significance of the skill level of the experimental group before, between, and after the experiment, it is clear that there are statistically significant differences at the level of 0.05 , between the tribal and inter-dimensional measurements in all variables of the skill level under consideration, where the values of the $\mathrm{p}$ calculated within the measurements ranged Between (150.23 and 363.56) these values are greater than the tabular value $(\mathrm{P})$ at the level of 0.05 . 
The least significant difference (L.S.D) was calculated for the difference between the average skill level of the experimental group before, between, and after the experiment, and the improvement ratios were calculated. My Schedule (18), (19). Attachment (3)

\section{- discussion:}

The differences are due to differences with statistical significance between the tribal, intra and post measurements in the physical variables under discussion among rhythmic gymnasts, and between each measurement and the next in favor of the next, to the effectiveness and nature of the proposed applied training program, which is based on the use of modern technical exercises represented in free exercises and With tools that were applied three times a week, where training was done on exercises and their movements were applied sequentially, collectively and regularly.

Free exercises contribute greatly to the development of the individual's ability and physical attributes through performing various skills such as jumping, jumping, balance, flexibility and running around the colleague, as they work to develop sensory-motor perception and neuromuscular compatibility. (27: 41), and that the movement exercises were employed in a correct way In training programs, it has a major impact on the development of physical and skill aspects (26: 60).

It is advised to use special training programs that require the performance of exercises that have close contact with the skills to be implemented in the motor sentence where the best training effect can be obtained if the nature of the exercises used is the same as the nature of performance in competition. (19:19), (28: 246), (31:111)

And the practice of gymnastics continuously and regularly leads to a significantly increased level of muscle strength when compared to the effort that non-practicing gymnasts are subject to. (6: 508)

The optimal method for developing the strength marked by speed and endurance is the same as the dynamic path during the exercise with the dynamic path of the skill itself, and training using exercises similar to the nature of performance leads to achievement in gymnastics, where this sport needs to characterize privacy by virtue of the nature of the performance of gymnastics skills. (3: 99)

The higher the degree of flexibility, the higher the level of skill performance and the impact on athletic results. On the contrary, the narrow range of work on the joints leads to obstruction of the level of showing strength and speed, which is reflected in the results of training directed at other motor characteristics. (2: 246)

One of the most important methods of developing agility is the use of exercises that dominate the change in speed, timing, performance of movement and direction. (37: 159) (32:117)

The improvement of compatibility has to do with the improvement of many physical characteristics, such as speed. The correlation of speed appears in the requirements of kinetic performance in terms of time, as compatibility is related to the form of grace and balance of 
movement requirements from the formal and spatial levels by moving the body or one of its parts with the required accuracy. (22: 163)

The differences are due to statistically significant differences between the tribal, intra-and dimensional measurements in the sensory system components under discussion among rhythmic gymnasts, and between each measurement and the next in favor of the next to the effectiveness and nature of the proposed applied training program that is based on the use of modern technical exercises represented in free exercises and tools And that was applied three times a week, where training was done on exercises and their movements were applied successively, collectively and regularly.

The main purpose of qualitative exercises with modern artistic exercises related to the kinesthetic sense is to promote the feeling of movement and the general form of skill and the ability to speed its performance and determine the positions of body parts in the void and the force required to contract. (16: 66), (42: 120)

Perception - kinesthetic is the ability to determine the positions and parts of the body in a vacuum and control the direction of the required distance during performance and to stabilize the body and not deviate in any direction, and on this is the correct descent and high accuracy of perceptions - kinetic (13: 13), (36: 82) (42:22), so gymnastics helps to develop a sense of balance, as well as control the body by a large amount compared to other types of sports. (35: 27 ), and that through the sequence and progression in the skills acquired during work leads to the development of sense perception - Kinetic. (14: 110)

The differences are due to differences with statistical significance between the tribal, intraand dimensional measurements in the level of skill performance of rhythmic gymnasts, and between each measurement and the next in favor of the next to the progress achieved in physical and variables of some elements of the sensory system, which was the result of applying the program using modern special technical exercises With the skills in question.

The development of the motor link helps to improve the level of compatibility, which in turn leads to improving the level of performance. (22: 46), the technical performance of the rotations in the stages of the kinetic performance of it depends on the movement of the arms with flexibility and the movement of the legs with force and speed in the movement of the pelvis, chest, trunk and shoulders with the rapid movement of the head and looking at a fixed point with the strength of the muscles of the legs and stability (15: 77)

And the development of perception-kinesthetic leads to an increase in the level of performance in skills, and the higher the level of performance in exercises, the less error in the perceptualkinetic tests, as confirmed by the results of studies (13), (14), (23), (7) ), (38), (39), which emphasized that regular training and the use of programs directed to the development of perceptual-motor lead to improving and developing the level of skill performance in exercise and gymnastics. 


\section{- Conclusions:}

- The use of modern artistic exercises represented by free exercises and tools that led to the improvement of some physical expressions and elements of the sensory system for rhythmic gymnasts under (12) years.

- The improvement in physical strippers among rhythmic gymnasts under (12) years as a result of using modern artistic exercises led to an improvement in the level of skill performance.

\section{- Recommendations:}

- The use of modern artistic exercises to improve physical expressions and the elements of the sensory system and the level of skill performance of rhythmic gymnasts.

Carrying out similar studies to know the effect of modern artistic exercises on various sports activities.

\section{- References:}

1- Salama,I.: The Practical Introduction to Measurement in Fitness, DarAl-Maarif, Alexandria, 2000 .

2- Abdel-Fattah,A.: Sports Training - Physiological Foundations, First Edition, Dar Al-Fikr AlArabi, Cairo, 1997.

3- Yousef,A.: Advanced Techniques in Training Gymnastics Using Basic Muscle Work, First Edition, Dar Al-Fikr Al-Arabi, Cairo, 2010.

4- Khater,A. \& Al-Baik,A.: Measurement in the Sports Field, Fourth Edition, Dar Al-Kitab AlHadith, Cairo, 1996.

5- Hussein,A.: The effect of some suggested exercises for developing kinesthetic perception on the level of performance in gymnastics, $\mathrm{PhD}$ thesis, Faculty of Physical Education for Boys in Cairo, 1986.

6- El Maraghy,A.: The effect of gymnastics on the dynamics of the growth of some forms of muscle strength during the 6-10 years phases, Journal of Research and Studies of Physical Education and Sports, Volume 48, Faculty of Physical Education in Alexandria, 2003.

7- Okdeh,O.: The effect of a proposed program of artistic exercises on developing perceptualkinesthetic and some cognitive and emotional processes for primary school pupils, $\mathrm{PhD}$ thesis, Faculty of Physical Education for Girls, Alexandria University, 1990.

8- Alaa El Din,G.: Laboratory studies in biomechanics, mathematical movements, second edition, Alexandria, 1986.

9- Alaa El Din ,G\& others: a dynamic study of the visual sense comparing the distance to some elementary stage students (8:12) in East Alexandria, the second conference for studies and studies of physical education, Faculty of Physical Education for Boys, Alexandria University, 1981. 
10- Alaa El-Din,G. , El-Sabbagh,N. \& Taha,A.: The Dynamic Age Characteristics of the Growth of Some Psychological Operations Among Middle School Students (12-16 Years), The Third Scientific Conference for Physical Education Research for Boys in Alexandria, Helwan University, 1982.

11- Alaa El-Din,G., El-Sabbagh,N. \& Taha,M.: A study of the effect of sports activities on the age dynamics of the growth of the sense of time among middle school pupils (13-16 years) in central Alexandria, the third scientific conference for physical education research for boys in Alexandria, University Helwan, 1982.

12- Alaa El-Din,G. , El-Sabbagh,N. \& Tolan,S.: A Dynamic Study of the Visual Sensual Comparison of Distance to Some Primary Stage Students (8-12 Years), East Alexandria District, The Second Scientific Conference for Studies and Research, Physical Education, Helwan University, 1981.

13- Ahmed,H.: The effect of using some methods of developing the muscular and visual sense on the speed of teaching the front somersaults on the hands, Master Thesis, Faculty of Physical Education for Boys, Alexandria University, 1985.

14- Ahmed,H.: A proposed program for developing sensory perception - dynamic to improve some of the kinematic variables of the anterior aerobic course in gymnastics, Ph.D., Faculty of Physical Education for Boys, Alexandria University, 1992.

15- Al-Hajrasi,S.: An Introduction to Exercise and Rhythmic Gymnastics, Faculty of Physical Education for Girls, Helwan University, 2001.

16- Husam Al-Din,T.: The Scientific Encyclopedia of Sports Training, Dar ELktab Alhdeth, 1997.

17 Al-Nimer, A, \& Al-Khatib,N.: Weight Training, Markz ELktab , Cairo 1996.

18- Barham,A.: Encyclopedia of Modern Gymnastics (Skills - Education - Training Measurement and Evaluation - Organization and Management - Arbitration - Mathematical Terminology), Dar Al-Fikr Al-Arabi, First Edition, 1995.

19- Ali,A.: The Circle Training - Its Foundations and Applications, The Egyptian Library, Cairo, 2004.

20- Al-Ashwal,A.: Developmental Psychology, The Anglo-Egyptian Library, Cairo, 2008.

21- Faraj,A.: Competitive Rhythmic Exercises and Sports Shows, Dar Al-Fikr Al-Arabi, Cairo, 2006.

22- Abdel-Khalek,E.: Mathematical Training, Theories and Applications, 11th Edition, Dar AlMaaref, 2005.

23- KhattabA, , \& Zahran,L.: Exercise for Girls, Eighth Edition, Dar Al-Maaref, Alexandria, 1997.

24- Muhammad,A.: Physiological Basis of Kinetic Activities, Zagazig, 2006. 
25- Al-Baik,A., Abu Zaid,A. \& Abda Khalil,M.: A Series of Modern Trends in Mathematical Training (Theories - Applications) Methods for Measuring Anaerobic and Aerobic Abilities, Part Two, Manshat Al-Maaref, Alexandria, 2008.

26- Ibrahim,F.: Scientific principles and foundations for physical exercises and sports shows, Dar Al-Wafa, Alexandria, 2008.

27- Ismail, K. \& Hassanein,M.: The foundations of sports training for developing physical fitness in physical education lessons in boys and girls schools (primary - secondary - general secondary and technical), first edition, Dar Al-Fikr Al-Arabi, Cairo, 1997.

28- Shehata,M.: Training of Contemporary Gymnastics, Third Edition, Faculty of Physical Education for Boys, Alexandria, 2003.

29- Shamoun,M.: Mathematical Psychology and Psychometrics, Markz ELktab, 2002.

30- Allawi,M. \&Radwan,M.: The Kinetic Performance Test, Dar Al-Fikr Al-Arabi, Second Edition, Cairo, 1989.

31- Allawi,M. \&Radwan,M: Kinetic Performance Tests, Dar Al-Fikr Al-Arabi, 1994.

32- Abdel Maqsoud,M.: A study of the use of some forms of marital exercises on some physical variables for middle school students, Master Thesis, Faculty of Physical Education for Boys, Alexandria University, 2003.

33- Hassanein, M.\& Abdel Hamid,K.: Physical fitness and its components - theoretical foundations - physical preparation - methods of measurement, Dar Al-Fikr Al-Arabi, second edition, Cairo, 1985.

34- Hassanein,M.: Measurement and Evaluation in Physical Education and Sports, Part One, Sixth Edition, Dar Al-Fikr Al-Arabi, Cairo, 2004.

35- Abdel-Salam,M.: Theory of Gymnastics, Equipment, Part 1, Faculty of Physical Education, Alexandria University, 1980.

36- Abbas,M. \& Yousef,A.: The Scientific Bases in Gymnastics Education and Training, Alexandria, 1999.

37- Hammad,M.: Modern Sports Training - Planning, Application and Leadership, Second Edition, Dar Al-Fikr Al-Arabi, Cairo, 2001.

38- Abdel-Al ,M.: The Effect of Specific Training for Sensory Perception - Dynamic for Improving the Technical Performance of the Forward-Sided Course on Balance Bar, Ph.D., Faculty of Physical Education for Girls, Zagazig University, 2002.

39- Abdel-Al,M.: Special physical preparation for rhythmic gymnasts in the light of the requirements of international law (technical value) and its effect on the level of free sentence performance, Journal of Comprehensive Education Research, Faculty of Physical Education for Girls, Zagazig University, 2007. 
40- Al-Sabbagh,N.: Dynamic properties of the types of perceptual-muscular and muscular-motor perception among middle school students (12-16 years), the third scientific conference for studies and researches in physical education, Faculty of Physical Education for Boys in Alexandria, Helwan University 1982.

41- Abd al-Rahman,N,: Modern Exercises - Its Origins and Components, Dar Al-Maarif, Alexandria, 1996.

42- Zakaria,Y., \&Abdullah,H,: An analysis of two straight, back-to-air antennas to descend from Al-Okla, International Scientific Conference - Strategy for Selecting and Preparing Sports Talents, Part Two, Faculty of Physical Education for Boys, Alexandria University, 2002.

43- Hamid, M, A: Overview of clinical anatomy and physiology of the vestibular system in: Arenberg I.K. (ED) Dizziness and balance Disorders. Kugler Publicatins. Amesterdam. The Netherland 1993.

44- nglis, J. T\&, Horak, F. B, Shupert, C. L, Jones, Rycewecz, C: The importance of somatosensory information in triggering and scaling automatic postural responses in humans, Exp Brain Res, 101L 1994.

45- Volker Dietz: Human neuronal control of automatic functional movements: interaction between central programs and afferent in put,: physiological review Vol.72no.1,33-69,1992.

46- spirduco,W., Francis,K. \& MacRae,P.: Physical Dimentions of Aging, 2nd, ed, human Kinetics, champaign, 2005. 


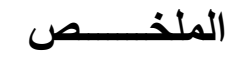

التأثيرات التدريبية للتمرينات الفنية الحديثة فى تحسين بعض المتغيرات البدنية والمنظومة الحسية لاى

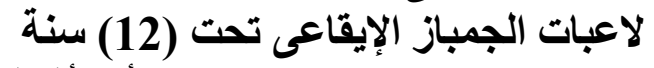

أ.د/ أشرف عبدالعال الزهرى

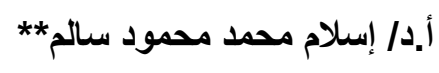

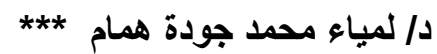

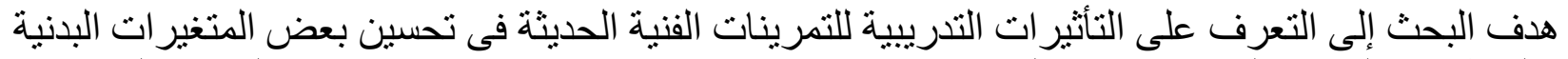

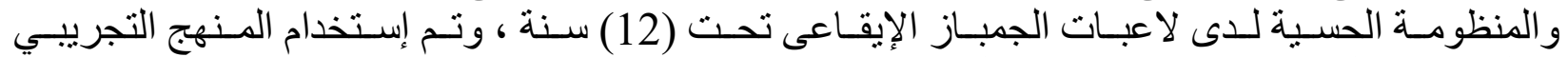

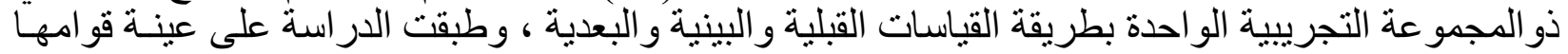

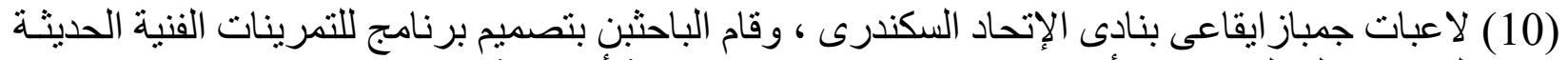

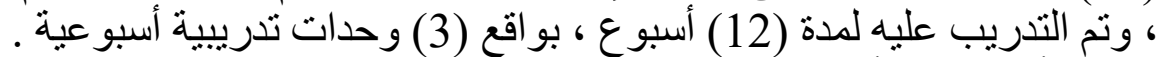

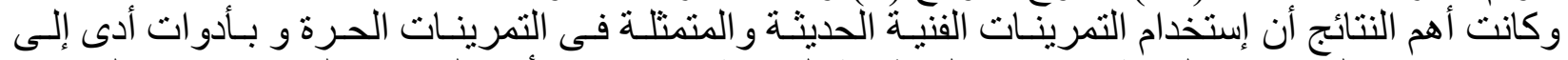

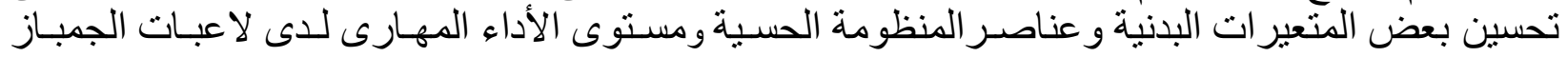
الإيقاعى تحت (12) سنة .

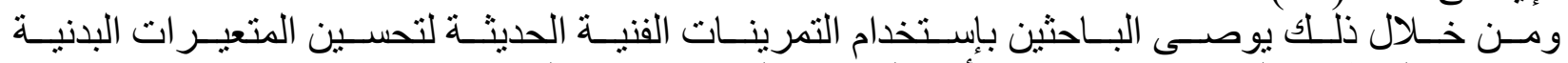

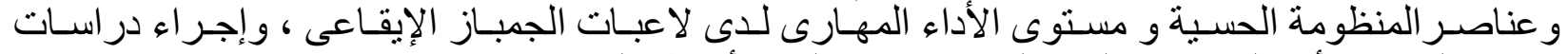

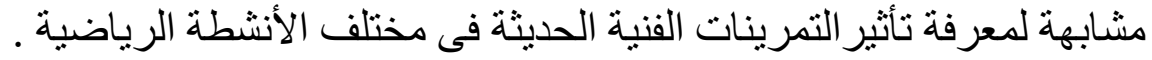

